\title{
PANDEMI COVID-19, MEMULUSKAN BISNIS PENIPUAN BERKEDOK JASA PINJAMAN UANG
}

\author{
Oleh: \\ Fatimah Aulia Rahma1, Agus Machfud Fauzi², Muh. Rizal S ${ }^{3}$ \\ ${ }^{1}$ FISH Universitas Negeri Surabaya; fatimah.20081@mhs.unesa.ac.id \\ ${ }^{2}$ FISH Universitas Negeri Surabaya; agusmfauzi@unesa.ac.id \\ ${ }^{3}$ FISH Universitas Negeri Makassar; rizalsuyuti@unm.ac.id
}

\begin{abstract}
ABSTRAK: Pandemi covid-19 telah melumpuhkan segala aspek kehidupan mulai dari aspek ekonomi, politik, hingga hukum. Dampak pandemi Covid-19 sudah dialami khususnya pada bidang ekonomi yang mengakibatkan terjadinya terjadinya kriminalitas yang terkait erat dengan kebutuhan finansial manusia. Hubungannya dengan pandemi covid-19 adalah tentang kebijakan pemerintah yang terkesan mendadak dan kurang memperdulikan rakyat kecil dan menengah, sehingga sebagian masyarakat melakukan segala cara untuk memenuhi kebutuhan hidup tanpa memikirkan resikonya. Mengingat kebijakan pemerintah dalam mengatasi pandemi covid-19 adalah pembatasan kegiatan masyarakat, larangan berkumpul dan melarang masyarakat beraktivitas di malam hari, membuat masyarakat kelabakan karena efek dari pembatasan sosial tersebut salah satunya adalah pengurangan tenaga kerja. Tujuan dari penelitian ini adalah untuk mengetahui seberapa besar dampak yang ditimbulkan oleh perubahan kebijakan pemerintah di masa pandemi dengan tingkat kriminalitas yang terjadi. Pendekatan yang digunanakan adalah penelitian deskriptif kualitatif dengan memfokuskan pada jenis kejahatan yang jarang dilakukan dan mudah untuk dikerjakan yaitu penipuan bisnis jasa pinjaman uang. Sasaran utama adalah masyarakat desa yang berprofesi sebagai pedagang, karena pedagang pada masa pandemi merosotnya penghasilan yang disebabkan oleh sepinya pasaran hingga habisnya modal untuk esok hari, hal tersebuat membuat pelaku kejahatan penipuan jasa simpan pinjam membidik para pedagang pasar, dengan dalih mereka akan meminjami modal usaha untuk membeli bahan pokok. Cara yang digunakan awalnya sangat halus dan meyakinkan sehingga membuat banyak yang percaya, namun pada akhirnya saat hutang tersebut jatuh tempo, para pelaku pinjaman online sangat berbeda tidak seperti pada saat menawarkan, mereka sangat memaksa untuk menagih hutang dengan bunga yang tinggi dan terkadang tidak segan-segan melalukan perampasan barang berharga dari korbannya untuk jaminan hutang. Sampai saat ini kasus tersebut belum ada yang melaporkan ke polisi, karena masyarakat masih belum paham prosedur dalam membuat laporan kepolisian.
\end{abstract}

KATA KUNCI: Covid-19, kriminalitas, kebijakan pemerintah, jasa pinjaman uang, modal usaha

\begin{abstract}
Pandemic covid-19 has crippled all aspects of life ranging from economic, political, to legal aspects. The impact of the Covid-19 pandemic has been experienced, especially in the economic sector, resulting in criminality that is closely related to human financial needs. The relationship with the covid-19 pandemic is about government policies that seem sudden and less concerned with small and medium-sized people, so that some people do everything possible to meet the needs of life without thinking about
\end{abstract}


the risks. Given the government's policy in overcoming the covid-19 pandemic is the restriction of community activities, the ban on gathering and prohibiting people from doing activities at night, making the community a club because of the effects of social restrictions, one of which is the reduction of labor. The purpose of this study is to find out how much impact the government policy changes in the pandemic with the level of criminality that occurs. The approach used is qualitative descriptive research by focusing on the type of crime that is rarely done and easy to do, namely the fraud of money loan services business. The main target is the villagers who work as traders, because traders during the pandemic slumped income caused by the quiet market until the end of capital for tomorrow, it is done to make the perpetrators of fraudulent lending services target market traders, on the pretext that they will lend business capital to buy basic materials. The method used initially is so subtle and convincing that it makes many believe, but in the end when the debt is due, the online loan actors are very different unlike when offering, they are very forced to collect debts with high interest and sometimes do not hesitate to take out valuables from their victims for debt guarantees. Until now, no one has reported to the police, because the public still does not understand the procedure in making a police report.

KEYWORDS: Covid-19, criminality, government policy, money lending services, business capital

\section{PENDAHULUAN}

Tindak kriminal merupakan salah satu bentuk kegiatan menyimpang dalam masyarakat, dan perilaku kriminal juga merupakan ancaman yang dianggap serius oleh masyarakat karena semua tindakan kriminal pasti akan selalu menyalahi nilai dan norma dalam masyarakat dan merusak keteraturan sosial. Jika kriminalitas tidak segera diberantas maka akan menimbulkan ketegangan individu maupun ketegangan sosial.

Salah satu kejahatan yang menjadi pokok kajian saya pada masa pandemi saat ini adalah kejahatan penipuan di kampung peneliti sendiri yang berada di Kabupaten Wonogiri, di mana banyak masyarakat sekitar tempat tinggal peneliti banyak yang mengalami kegagalan ekonomi salah satunya adalah berhentinya sektor usaha perdagangan karena faktor kekurangan modal usaha. Hal tersebut menjadi celah untuk orang-orang yang tidak bertanggung jawab. Banyak orang yang datang ke daerah peneliti untuk memulai bisnisnya yaitu usaha pinjaman modal, sasaran utama dari agen bisnis ini adalah para pedagang yang hampir gulung tikar, mereka memanfaatkan keadaan tersebut karena tahu bahwa banyak masyarakat yang hampir menyerah karena keadaan finansial saat pandemi seperti ini. Namun perlu diketahui bahwa usaha yang mereka jalankan sebenarnya malah merugikan masyarakat sendiri, memang awalnya masyarakat terbantu dengan adanya pinjaman uang dari pihak yang mengatasnamakan dirinya sebagai koperasi simpan pinjam (KSP) ini, namun saat jatuh tempo masyarakat yang meminjam uang pada koperasi tersebut tidak dibri kelonggaran waktu dan wajib mengembalikan uangnya dengan bunga hingga dua kali lipat hingga perampasan barang berharga secara paksa.

Indonesia sebenarnya sudah memiliki sanksi pidana terhadap kasus seperti ini, karena nasabah dari koperasi tersebut jelas tidak mendapatkan perlindungan dari pihak manapun. OJK dalam kasus ini telah tegas memberi sanksi kepada layanan usaha pinjaman uang yang tidak terdafdar dan melanggar aturan OJK sendiri. Hal tersebut diatur dalam aturan OJK Nomor 77/POJK.01/2016. Kasus yang menimpa masyarakat sekitar tempat tinggal saya sudah sempat dilaporkan kepada pihak 
yang berwajib, namun belum ada kejelasan dari kasusnya dan kegiatan tagih menagih hutang pun tetap berjalan. Sudah seharusnya perhatian dari banyak pihak terkait hal tersebut perlu digalakkan, terutama aparat penegak hukum sudah harus melaksanakan tugas dengan baik dan adil serta transparan. Pemerintah daerah dalam hal ini benar-benar dibutuhkan perannya dalam mengatur kebijakan usaha yang berizin serta tidak menguntungkan diri sendiri saja, misalnya pemerintah mengatur pembatasan akses usaha yang masuk ke suatu daerah atau perkampungan,jika ada yang melanggar dan tetap nekat untuk mencari nasabah maka konsekuensi yang didapatkan juga harus memberikan efek jera. Sudah banyak kasus seperti ini yang terjadi di sekitar tempat tinggal saya di Kabupaten Wonogiri, korban hanya bisa kaget dan terdiam saat sang penaggih hutang menyebutkan dana yang harus dibayar saat jatuh tempo. Cukup miris sebenarnya rakyat miskin yang sedang kesulitasn ekonomi malah dibebani bunga pinjaman yang hampir dua kali lipat, bahkan ketika korban tidak mampu melunasi hutangnya saat jatuh tempo rentenir tidak segan-segan merampas barang berharga korban seperti sepeda motor, padahal harga sepeda motor tidak sebanding dengan uang yang telah dipinjam korban, namun itulah kondisi yang saat ini terjadi di Kabupaten Wonogiri. Bahkan pelaku penipuan buang pinjaman ini ternyata bukan berasal dari Pulau Jawa melainkan berasal dari luar Jawa, itu artinya ada pihak yang membawa pelaku hingga ke Kabupaten Wonogiri, Hal yang terlupakan oleh pihak yang berwenang adalah sosialisasi dan perlindungan terhadap para korban, masyarakat di Kabupaten Wonogiri tidak mengerti tentang manajemen uang yang baik maka hal tersebut membuat masyarakatnya mudah dibuai dengan jaminan-jaminan yang semu dan mudah ditipu daya. Namun beberapa korban sudah ada yang melaporkan kasus ini baik ke polisi, dinas sosial maupun langsung pada sekertaris bupati, namun hingga sekarang hasilnya nihil, sang rentenir terus berkeliaran mengintai orang yang sedang terpuruk ekonominya. Maka dari itu sebisa mungkin aparat penegak hukum melakukan patrol ke daerah-daerah yang rawan dimasuki rentenir, agar masyarakat merasa aman dan tidak mudah diperdaya.

\section{METODE PENELITIAN}

Jenis penelitian yang digunakan dalam penelitian ini adalah bersifar deskriptif kualitatif, dimana penelitian ini nantinya akan memperdalam deskripsi dan berlandaskan pada filsafat positivisme, digunakan untuk meneliti objek yang bersifat alamiah yaitu peneliti menjadi instrument kunci. Metode yang digunakan dalam penelitian ini menggunakan metode deskriptif kualitatif dikarenakan peneliti akan mendeskripsikan bagaimana kejahatan mengenai penipuan terjadi di sekitar lingkungan tempat tinggalnya.

Pada penelitian ini pula memiliki karakteristik alami (natural setting) sebagai sumber data langsung, pada penelitian ini nantinya proses analisis lebih diutamakan daripada hasil penelitian. Analisis dalam penelitian kualitatif cenderung dilakukan secara analisa induktif serta makna merupakan hal yang esensial.

Dalam penelitian menggunalan studi kasus dimana penelitian akan dilaksanakan untuk mempelajari latar belakang keadaan sekarang secara intensif, serta lingkungan suatu unit sosial maupun kelompok.

\section{HASIL DAN PEMBAHASAN}

Teori yang digunakan dalam penelitian ini berorientasi pada tempat kejahatan dan jenis kejahatan yang terjadi di Kabupaten Wonogiri selama masa pandemic covid-19. Dalam penelitian ini jumlah teori yang digunakan sebanding dengan variabel yang diteliti yaitu dari pelaku kejahatan penipuan dan korban penipuan. Teori yang akan digunakan juga harus disesuaikan dengan fenomena yang berkembang di lapangan.

Teori lensa sering juga disebut teori prespektif (Cresswell: 2009), hal tersebut mengandung artian bahwa lensa dalam perspektif teoritis dalam penelitian kualitatif memberikan orientasi keseluruhan yang digunakan untuk mempelajari pertanyaan masalah-masalah sosial dari kelompok 
marjinal yang membentuk jenis pertanyaan apa yang bisa diajukan sebagai dasar informasi bagaimana fenomena sosial dikumpulkan dan dianalisis untuk mengetahui tentang apa yang sebenarnya terjadi di lapangan.

Perjanjian dalam hutang piutang adalah suatu hal yang penting dalam mencapai perlindungan hukum yang sah di negara Indonesia baik pada pihak yang berhutang atau pada pihak yang memberi hutang.Maka dari itu ada beberapa syarat yang harus dipenuhi dalam perjanjian hutang piutang ini yan melibatkan kedua belah pihak yaitu pihak yang berhutang dan pihak yang memberi hutang. Syarat tersebut diantarannya adalah pasal 1320 KUHPerdata yaitu: (1) Kesepakatan yang mengikat kedua belah pihak. (2) Kecakapan dalam membuat suatu perikatan. (3) Suatu pokok persoalan tertentu. (4) Suatu sebab yang tidak terlarang. Pasal tersebut di atas merupakan pasal yang menjadi acuan dalam berdirinya sebuah perjanjian yang sah menurut undaangundang.

Terbentuknya sebuat kesepakatan atau akad dalam sebuah perjanjian adalah suatu hal yang penting, maka dari itu landasan hukum negara yang sah memegang kendali yang kuat dalam perjanjian ini. Namun pada kenyataan di lapangan terkadang masih ada yang berbeda, karena kesepakatan yang dibuat masih berupa penipuan, paksaan dan kekerasan. Dalam beberapa kasus kecacatan dalam pembentukan kesepakatan perjanjian sudah lama berkembang di Indonesia, hal ini setara dengan kasus yang seringkali menjerat rakyat menengah kebawah dan melindungi bagi pemilik kekuasaan. Dianalogikan pada pernyataan tersebut rakyat menengah ke bawah adalah seorang yang berhutang dan rakyat memegang kekuasaan adalah orang yang memberi hutang. Penelitian memfokuskan kajian pada kasus jasa pinjaman uang di Kabupaten Wonogiri yang memiliki suku bunga hingga lebih dari dua kali lipat.

Yang terjadi saat masa pandemi covid-19 adalah masalah ekonomi yang mencekik masyarakat miskin, diantara masalah-masalah tersebut adalah penghapusan hubungan kerja dari perusahaan secara massal, ruang gerak pedagang yang dibatasi dan penerapan jam malam. Padahal sebagian dari masyarakat kelurahan Wonoharjo, Kabupaten Wonogiri adalah bekerja sebagai buruh pabrik dan pedagang, jika terjadi pemecatan secara masal maka penghasilan sebagian mayarakat Wonogiri jelas tidak ada, disamping itu banyak pabrik yang tutup dan sudah tidak menerima karyawan lagi. Untuk pedagang yang ruang geraknya dibatasi juga merasakan hal yang sama, penghasilan yang menurun derastis dikarenakan sepinya pasar dan tidak ada uang yang diputar untuk modal usaha. Masalah sosial tersebut jelas menyulitkan bagi sebagian masyarakat, banyak orang yang melakukan segala cara untuk bertahan hidup ditengah kondisi pandemi covid-19. Banyak cara yang dilakukan masyarakat mulai dari merambah bisnis yang masih bisa di jalankan seperti berjualan masker namun tidak semua orang bisa melakukannya dikarenakan tidak semua orang memiliki cukup modal untuk memulai usaha tersebut .

\section{Sejarah Singkat Masuknya Rentenir di Kelurahan Wonoharjo}

Yang akan saya bahas pada penelitian ini adalah tindak penipuan yang dilakukan dilakukan oleh jasa pinjaman uang yang menamai dirinya sebagai koperasi simpan pinjam, penelitian ini dilakukan di Kelurahan, Wonoharjo, Kabupaten Wonogiri Provinsi Jawa Tengah, tepatnya di sekitar tempat tinggal peneliti. Pada tahun-tahun sebelumnya telah banyak rentenir yang memasuki wilayah pasar di Kabupaten Wonogiri bahkan sebelum pandemi covid-19 ini melanda. Pada kasusnya diawali dengan pembagian selebaran yang dilakukan oleh orang yang tidak dikenal yang memasuki wilayah pasar dan perkampungan warga. Selebaran tersebut berisikan penawaran pinjaman tunai bagi siapa saja yang sedang terhimpit masalah ekonomi dan disertai buanga cicilan pembayaran per bulan, yang peneliti lakukan saat itu adalah meminta selebaran dari warga yang menerima kemudian dianalisis, hasilnya rata-rata bunga pinjaman pertahun adalah sebesar $10 \%$ dan syarat untuk melakukan pinjaman adalah dengan BPKB motor. 
Kemudian peneliti bertanya pada salah satu warga yang pernah meminjam uang kepada jasa pinjaman uang yang yang ada pada brosur, menurut salah satu warga meminjam uang dengan jaminan BPKB bukanlah suatu yang sulit, karena jika hanya BPKB yang diserahkan pada pihak koperasi simpan pinjam, namun motor dari penerima hutang tidak diberikan dan masih bisa digunakan oleh pemiliknya. Celakanya hal tersebut semakin lama semakin membuat masyarakat lengah dan menjadi kebiasaan baru di kalangan masyarakat, doktrin dari luar menjadikan masyarakat mudah terhasut oleh tawaran hutang piutang dengan jaminan BPKB motor. Masyarakat merasa terbantu dengan adanya hutang yang mudah didapatkan dengan syarat yang tidak ribet. Semakin lama banyak jasa pinjaman hutang yang mendatangi pemukiman warga dan lingkungan pasar. Karena tidak dapat tidak dapat dipungkiri bahwa masyarakat di Kelurahan Wonoharjo telah terpengaruh oleh mudahnya meminjam uang dari jasa pinjaman uang yang belun tentu berstatus hukum resmi.

Setelah peneliti mengamati setiap transaksi yang terjadi di lingkungan pasar Wonoharjo, akan selalu ada orang baru yang hampir datang setiap hari untuk menagih cicilan, dan orang-orang yang datang tersebut berasal dari perusahaan jasa pinjaman yang berbeda. Hal ini mengartikan bahwa ada satu prang yang memiliki hutang di lebih dari satu jasa pinjaman uang. Peneliti mencoba mewawancarai salah salah satu warga yang meminjam uang di perusahaan jasa pinjaman, berawal dari kisah beliau yang bernama Ibu Sumiarti warga Desa Wonoharjo, beliau mengaku telah memiliki hutang kepada tiga perusahaan pinjaman uang. Mendengar jawaban dari ibu Sumiarti tersebut menandakan bahwa pihak perusahaan pinjaman uang tidak mempermasalahkan meminjamkan uang kepada seseorang yang telah memiliki hutang pada pihak lain. Dan diakhir wawancara ibu Sumiarti juga mengatakan bahwa dirinya telah memberi tahu tetangganya untuk melakukan hal yang sama dengannya, yaitu meminjam uang kepada jasa pinjaman uang yang berbedabeda, dalam hal ini ibu sumiarti secara tidak langsung tekah melalukan promosi jasa pinjaman uang kepada para tetangganya yang menurut beliau sedang terhimpit masalah ekonomi dan tidak cukup kebranian untuk meminjam uang ke bank dikarenakan tidak ada yang bisa untuk dijadikan jaminan ke bank.

\section{Masyarakat Kelurahan Wonoharjo yang Mudah Terhasut Rayuan Pinjaman Uang}

Mayarakat Kelurahan Wonogarjo
rata-rata adalah masyarakat menegah kebawah yang tingkat pendidikannya tidak terlalu menjadi perhatian, menurut bapak Parmin selaku kepala desa wonoharjo, beliau menjelaskan bahwa rata-rata penduduk Desa Wonoharjo yang berusia 18-35 tahun sebanyak $85 \%$ hanya menyelesaikan pendidikan hingga tingkat SMA/SMK sederajat, sedangkan sisanya sebanyak $15 \%$ penduduk usia tersebut mampu menyelesaikan pendidikan hingga tingkat diploma/sarjana. Pendidikan adalah suatu hal yang penting dalam majunya sebuah wilayah, semakin banyak penduduk dalam suatu wilayah berhasil menempuh pendidikan tinggi maka akan semakin maju wilayahnya begitu pun sebaliknya. Salah satu pencapaian dari penduduk yang cerdas dalam suatu wilayah adalah masyarakat yang kritis dan ingin memiliki rasa ingin tahu yang lebih dalam setiap perubahan yang terjadi dalam masyarakat, artinya masyarakat tidak mudah terhasut dengan apapun yang secara tiba-tiba masuk ke dalam lingkungan masyarakat. Dalam hal ini peneliti akan menekankan pada kasus masuknya rentenir ke dalam wilayah pedesaan khususnya di Kelurahan Wonoharjo.

Masyarakat Kelurahan Wonoharjo selama pandemi banyak yang terhimpit masalah ekonominya, hal tersebut menyebabkan masyarakat harus memutar otak untu bisa makan sehari-harinya, Kehadiran Jasa pinjaman uang atau jasa kredit pinjaman menjadi penyelamat di balik di balik selimut saat masa pandemi covid-19 saat ini, masyarakat merasa tenang setelah berhasil meminjam yang kepada jasa pinjaman uang, karena mudahnya syarat untuk meminjam uang yaitu hanya dengan 
jaminan BPKB kendaraan bermotor. Selama pandemi telah banyak Karyawan dari berbagai perusahaan jasa pinjaman uang yang datang ke Kelurahan Wonoharjo, cara mereka untuk promosi beragam, mulai dari menyebar selebaran brosur, menawarkan dari rumah ke rumah warga, bahkan ada yang dengan membawa langsung uang yang akan ditawarkan kepada nasabah yang menjadi target. Mudahnya masyarakt terhasut oleh bujuk rayu semacam itu membuat para perusahaan pinjaman uang menjadikan masyarakat Kelurahan Wonoharjo menjadi sasaran empuk dalam bisnisnya yang berliku ini. Pertama hanya ada satu hingga dua orang yang benar-benar berniat meminjam uang pada jasa pinjaman uang ini, namun salah satu dari masyarakat tersebut kemudian menawarkan pada tetangganya yang menurutnya sedang terhimpit masalah ekonomi, kemudian semakin lama masyarakat semakin percaya bahwa meminjam uang pada jasa pinjaman uang aman-aman saja dan tidak pernah ada kasus yang merugikan nasabah.

Di Kelurahan Wonoharjo sendiri, belum ada sosialisasi dari pihak berwenang yang menanggani kasus ini, padahal jika dibiarkan akan menjadi kebiasaan baru masyarakat yang tidak dapat dihindarkan, pihak terkait yang dimaksud adalah kaur atau sekertaris desa bagian Pemberdayaan Masyarakat dan seksi bagian Kesejagteraan sosial. Menurut Ketua Seksi Pemberdayaan masyarakat yaitu bapak Muh Sulistyo, beliau menjelaskan bahwa selama pandemi sekertaris desa telah melakukan pemberdayaan dalam bidang ekonomi dan pengajaran bisnis rumahan terpadu.

Ketika peneliti menanyakan prihal sosialisasi mengenai banyaknya masyarakat yang berhutang pada Koperasi simpan pinjam atau jasa pinjaman lain, beliau mengatakan bahwa hanya sebagian kecil saja masyarakat kelurahan wonoharjo yang meminjam uang pada koperasi simpan pinjam atau jasa pinjaman lain. Sosialisasi tentang cara meminjam uang yang aman merupakan suatu hal yang penting yang harus disampaikan pada masyarakat, namun pada kenyataannya yang terjadi di Kelurahan Wonoharjo sosialisasi tentang cara meminjam uang yang aman belun disosialisasikan. Seksi bagian pemberdayaan masyarakat hanya fokus terhadap pengembalian kondisi ekonomi tanpa memperhatikan masyarakt yang sudah terlanjur berhutang ke banyak pihak. Padahal kebijakan pemerintahan desa bisa mengendalikan hal tersebut agar tidak lagi terjadi di Kelurahan Wonoharjo. Seperti yang dilansir dari harian kompas ada sebuah dusun di Yogyakarta yang melarang adanya praktik rentenir, larangan tersebut telah disampaikan langsung oleh Kepala Desa Ngoro-oro, Gunung Kidul, Yogyakarta, bahkan di setiap gang untuk masuk ke desa ini telah dipasang spanduk bertuliskan "Rentenir dilarang Masuk". Berkaca dari Desa Ngoro-oro tersebut seharusnya bisa dijadikan pembelajaran pagi Pemerintahan Kelurahan Wonoharjo, mengingat warga masyarakat yang meminjam uang atau berhuutang kepada jasa pinjaman uang semakin banyak dan mengkhawarirkan.

Minimal kepala desa bisa memberi himbauan kepada masyarakatnya untuk tidak asal menerima tamu yang berusaha menawarkan dana atau hutang, hal tersebut adalah yang paling minimal bisa dilakukan oleh kepala desa jika sosialisasi memang benar-benar bisa dilakukan. Di pihak lain juga dibutuhkan kerja sama bahu membahu dalam mengatasi masalah ini, pihak lain yang dimaksud adalah perangkat desa setempat dan warga masyarakat. Maka ketegasan dari seorang pemimpin sangat diperlukan dalam melumpuhkan usaha rentenir atau jasa pinjaman uang dengan bunga yang tinggi, agar masyarakat merasa aman dan tidak dirugikan oleh siapapun.

\section{Masuknya Rentenir Luar Pulau yang Membawa serta Anak Buahnya Bak Preman}

Yang paling menarik perhatian di Kelurahan Wonoharjo ini adalah Jasa Pinjaman uang yang awalnya mengaku sebagai Perusahaan Multifinance. Rentenir kali ini merupakan rentenir asal Pulau Sumatra yang datang ke Kelurahan Wonoharjo, Rentenir ini dibawa oleh salah seorang warga Kelurahan Wonoharjo yang bernama Heny, Heny tersebut merupakan seorang Buruh Pabrik, menurut keterangan dari Ibu Daryatmi salah satu warga yang 
mengenal sosok Heny, beliau menjelaskan bahwa Henny dengan sengaja menghubungi rentenir asal pulau Sumatra untuk bisa menjalankan bisnisnya di sekitar pasar dan sekitar Kelurahan Wonoharjo, karena Heny melihat bahwa warga masyarakat Kelurahan Wonoharjo adalah orang-orang yang gemar berhutang dan orang-orang yang mudah termakan bujuk rayu. Pada akhirnya tibalah tim rentenir asal Sumatera tersebut ke pasar Kelurahan Wonoharjo, satu tim rentenir berasal kurang lebih ada lima orang, orangorang yang datang Ini berpenampilan layaknya mafia dan menggunakan motor gede.

Tim Rentenir asal Sumatra ini awalnya mendatangi lokasi pasar dan mendangi kios Ibu Sumiarti, Kios ibu sumiarti ini memang kerap dijadikan basecamp bagi tim rentenir asal Sumatra tersebut, Setiap hari Rabu akan selalu ada banyak ibu-ibu yang mendatangi kios ibu sumiarti, bukan untuk membeli barang daganggannya melainkan untuk menemui tim rentenir asal Sumatra dengan tujuan untuk meminjam uang atau membayar cicilan hutang. Yang menjadi perhatian dari segi ranah kriminalitas adalah suku Bunga yang diberikan tim rentenir asal Sumatra tersebut sangat mencekik leher, untuk hutang jangka waktu satu tahun penerima hutang bisa dibebankan suku bungga $80 \%$ hingga $100 \%$, artinya bungga yang dibayarkan sangat mungkin hampir sama bahkan sama persis nominalnya dengan jumlah uang yang dipinjam, padahal aturan mengenai suku bunga telah diatur di dalam Peraturan Pemerintah No. 89 Tahun 2014 tentang suku bungga pinjaman atau imbal hasil pembiayaan dan luas cakupan wilayah usaha lembaga keuangan mikro yang menjelaskan tentang kewajaran penerapan suku bunga. Dan yang lebih penting adalah jasa rentenir asal Sumatra ini tidak dinaungi oleh Otoritas Jasa Keuangan (OJK), dan itu berarti keamanan nasabah sangat diragukan, padahal segala perusahaan yang memfasilitasi aktivitas hutang piutang harus terdaftar di OJK, namun nyatanya rentenir asal Sumatera ini bukan merupakan sebuah perusahaan jasa melainkan hanya bisnis pribadi, yang jelasjelas tidak terdaftar di badan hukum.

\section{Perampasan Barang penah dilakukan oleh Rentenir asal Sumatra.}

Kisah ini berawal dari salah seorang warga bernama Ibu Giyatun, warga kelurahan Wonoharjo yang sedang kebingungan dikarenakan beliau memiliki banyak hutang pada lembaga pinjaman uang bukan bank, menurut pengakuannya beliau telah memiliki hutang pada lebih dari empat rentenir yang wara-wiri di Kelurahan Wonoharjo, Dan yang terahir beliau meminjam uang pada rentenir asal Sumatra yang seluruh timnya berpenampilan layaknya preman. Ibu Sumiarti mengaku meminjam uang sebesar lima juta rupiah kepada rentenir asal Sumatra, namun ketika jatuh tempo Ibu Giyatun diharuskan membayar sebesar Sembilan juta rupiah, mendengar hal tersebut membuat ibu sumiarti kaget dan kelabakan, kemudian ibu Giyatun meminta pada pihak rentenir untuk memberi tambahan waktu untuk mengembalikan uangnya, permintaan tersebut dikabulkan oleh pihak rentenir asal Sumtera tersebut dan ibu Giyatun diberi tambahan waktu seminggu untuk melunasi hutangnya.

Tibalah waktu seminggu setelah perpanjangan waktu Ibu Giyatun dihubungi pihak rentenir tersebut di salah satu rumah makan di Kabupaten Wonogiri lokasinya di pusat kota, Ibu Giyatun menggunakan sepeda motor sendirian untuk mendatangi lokasi yang ditentukan pihak rentenir, Ibu Giyatun juga membawa sejumlah uang sesuai perjanjian sebelumnya, ternyata Ibu Giyatun hanya membawa uang sejumlah delapan juta rupiah dan masih kurang satu juta rupiah agar hutangnya terlunasi, ibu Giyatun memohon keringanan pada bos rentenir asal Sumatra lagi dan kali ini usahanya untuk memperoleh keringanan tidak dikabulkan, Ibu Giyatun sudah menangis di tempat namun air matanya sia-sia dan tidak bisa meluluhkan hati dari bos rentenir asal Sumatera tersebut. Alhasil sepeda motor yang yang digunakan ibu Giyatun untuk mendatangi lokasi tadi disita oleh pihak rentenir beserta surat-suratnya, padahal motor tersebut bukan motor milik ibu Giyatun melainkan motor milik kekasih anaknya yang sedang dipinjamkan kepada beliau, karena motor pribadi ibu Giyatun ternyata sudah digadaikan ke pihak lain. Ibu 
Giyatun pulang dengan diantar anak buah rentenir asal Sumatra tersebut, sesampainya di rumah ibu Giyatun kebingungan dan segera mencari bantuan kepada para tetangganya untuk meminjam uang, namun tidak ada satupun tetangga yang mau meminjaminya uang dikarenakan ibu Giyatun sudah sering meminjam uang kepada rentenir dan hanya untuk menggali lubang menutup lubang saja. Keesokan harinya ibu sumarti melaporkan kejadian yang menimpanya kepada kepala desa Kelurahan Wonoharjo dan kepada ketua ibu-ibu PKK, bahkan ibu Giyatun sempat meminjam bantuan hutang kepada PKK, namun hasilnya tidak dikabulkan, dan saat ini ibu Giyatun hanya mengandalkan perlindungan dari pemerintahan kelurahan agar dirinya tidak diganggu oleh pihak rentenir asal Sumatra terlebih dahulu.

Hal yang menjadi titik kriminalitas rentenir asal Sumatra ini selain suku bungga yang diluar batas kewajaran adalah pihak rentenir memanjangkan secara otomatis hutang nasabahnya, salah satu warga yang berhutang pada rentenir asal Sumatera ini mengaku jika hutangnya sudah lunas, namun diperpanjang oleh pihak rentenir atau dibutakan kembali hutangan yang baru tanpa manawarkannya terlebih dahulu pada pihak yang bersangkutan. Hal ini jelas-jelas membuat masyarakat resah akan kehadiran rentenir asal Sumatra tersebut karena telah melakukan penipuan dan memeras warga masyarakat Kelurahan Wonoharjo.

\section{Dasar Hukum yang Bisa Menjerat Hadirnya Rentenir di Indonesia}

Pada dasarnya yang disebut bank gelap adalah pihak-pihak yang menjalankan kegiatan seolah-olah menyetarai bank, sebagaimana diatur dalam UU No. 10 Tahun 1998 tentang perubahan atas UU No. 7 Taun 1992 tentang perbankan.

Pasal 46 ayat(1) UU No 10/1998, berbunyi "Barang siapa yang menghimpun dana dari masyarakat dalam bentuk simpanan tanpa izin dari pimpinan bank Indonesia sebagaimana yang dimaksud dalam pasal 16, diancam dengan pidana penjara sekurang-kurangnya 5(lima) tahun dan paling lama 15 (lima belas) tahun serta denda sekurang- kurangnya $\mathrm{Rp} 10$ miliar dan paling banyak Rp 200 miliar".

Dari pasal di atas jelas menghimpun dana dari masyarakat seperti yang dilakukan para rentenir adalah perbuatan yang dilarang negara. Syarat mutlak rentenir bila dilaporkan pada pihak berwajib adalah ketika memberi suku bunga pinjaman sebesar lebih dari $10 \%$. Kasus rentenir asal Sumatra yang telah dijelaskan sudah pasti melanggar pasal 46 ayat (1) UU No 10/1998. Karena dari kasus yang sudah terjadi rentenir asal Sumatra tersebut menarik suku bungga berkisar $80 \%$ hingga $100 \%$ atau setara dengan dua kali lipat.

\section{PENUTUP}

Penyalahgunaan keadaan benarbenar terjadi di Indonesia, terlebih saat masa pandemi covid-19 seperti ini yang melumpuhkan kegiatan ekonomi, politik dan pendidikan pada masyarakat Indonesia. Kasus pinjam meminjam uang antara rentenir dengan nasabahnya merupakan kasus nyata penyalahgunaan keadaan pada saat pandemi covid-19 ini. Terdapat beberapa masalah yang ditimbulkan dengan adanya rentenir masuk ke dalam perkampungan warga dan mempengaruhi masyarakat yang melemah secara ekonomi. Maka setelah dilakukan penelitian ini diharapkan para tokoh masyarakat ataupun akademisi hukum dan sosiologi dapat membantu menghilangkan praktik-praktik ilegal yang mengatasnamakan bantuan uang agar masyarakat tidak semakin terpuruk keadaannya dengan tanggungan bunga yang melewati batas aturan undang-undang.

Layanan transaksi pinjaman modal dapat dilakukan oleh pihak penyedia jasa, apabila mengikuti aturan, salah satunya adalah perusahaan telah terdaftar di OJK. Bunga yang dibebankan pada nasabah juga tidak lebih dari $10 \%$ dari total pinjaman. Dampak positif dari hadirnya penyedia jasa pinjaman uang adalah membantu masyarakat yang membutuhkan dana cepat, sepanjang jasa pinjamannya tidak ilegal, dan dampak negatifnya hal tersebut bisa menjadikan warga masyarakat terbiasa berhutang dan memunculkan budaya gali lubang tutup lubang. Jika kebiasaan masyarakat akan 
berhutang telah menjadi trend, maka semua pihak harus membantu menyelesaikan permasalahan ini, terlebih jika dari awal memang tidak ada edukasi mengenai aturan hutang piutang.

\section{DAFTAR PUSTAKA}

Maidin, Sabir, and Rifka Tunnisa "JAMINAN FINDUSA DALAM TRANSAKSI PERBANKAN (Studi Komparatif Hukum Positif dan Hukum Islam)" Mazaibuna; Jurnal Perbandingan Mahzab 2, No.01 (2020).

Amiruddin, Muhammad Majdy, Nasrullah bin Sapa, and Abdul Syatar. "Uncovering Wastathiyah Values on Sharia Banking" Al-Mashrafiyah: Jurnal Ekonomi, Keuangan dan Perbankan Syariah 4, No.2 (2020): 15- 21

Ahmad Arif, Syarif, "Penyalahgunaan Keadaan Dalam Perjanjian Pinjam Meminjam

Uang Rentenir" . Lex Renaissance No. 2 Vol. 2 Juli 2017

Buku KUH Perdata (Burgerlijk Wetboek) hal.144. Cetakan Pustakan Baru Press

Wawancara dengan seksi bidang pemberdaaan masyarakat Kelurahan Wonogarjoh, Bapak Muh Sulistyo, Wonoharjo : 21 Februari 2021 pukul 10.10

Wawancara dengan Ibu Sumiarti, Wonoharjo: 21 Februari 2021 pukul 12.30

Wawancara dengan Ibu Daryarmi, Wonoharjo: 23 Februari 2021 pukul 08.30

Wawancara dengan Ibu Giyatun, Wonoharjo: 23 Februari 2021 pukul 17.53 